\title{
PUBLIC HEALTH IMPLICATIONS OF TOXOPLASMOSIS IN ANIMALS AND WOMEN IN SELECTED LOCALITIES OF MENOUFIA GOVERNORATE, EGYPT
}

\author{
AHMED BYOMI ${ }^{1}$; SHERIF ZIDAN ${ }^{1}$; AKRAM SALAMA ${ }^{2}$; AHMED ELSIFY ${ }^{2}$; \\ GHADA HADAD ${ }^{1}$ and NOURHAN EISSA ${ }^{1}$ \\ ${ }^{1}$ Department of Animal Hygiene and Zoonoses, Faculty of Veterinary Medicine, University of Sadat City, Egypt \\ ${ }^{2}$ Department of Animal Medicine and Infectious Diseases, Faculty of Veterinary Medicine, University of Sadat City, Egypt
}

Received: 31 March 2018; Accepted: 30 April 2018

\begin{abstract}
Toxoplasma gondii is an important protozoan with serious obstetric impact in animals and women. The work aimed to relate public health significance of toxoplasmosis among some animals and women in Menoufia Governorate. A total 50 blood samples were collected from 50 adult sheep (30 from Kafr Tanbidi and 20 from Shebein El-Kom) and a total of 31 cattle milk samples were collected from different localities in Shebein ElKom. Sheep sera were examined by ELISA IgG and recorded seropositivity of 60\% (30/50) with 66.67\% (20/30) were positive in Kafr Tanbidi and 50\% (10/20) in Shebein El-Kom. PCR on sheep blood recorded 22\% (11/50), of them 20\% (6/30) were positive in Kafr Tanbidi and 25\% (5/20) in Shebein El-Kom while PCR on cattle milk revealed 19.35\% (6/31) positive for Toxoplasma DNA. On the other hand, Toxoplasma seroprevalence among 250 women was $54.4 \%(136 / 250)$ by ELISA IgG and 8.4\% (21/250) by ELISA IgM. There was a significant association between IgG seroprevalence and age, increased gravidity, abortion, climate, cat contact, consumption of raw cow milk, undercooked meat and contaminated water from wells and between IgM seroprevalence and age, abortion and climatic conditions prevailed during sampling.
\end{abstract}

Key words: Toxoplasma gondii, ELISA IgG, ELISA IgM, PCR.

\section{INTRODUCTION}

Toxoplasmosis is one of the global major anthropozoonotic parasitic diseases infecting humans directly from animals (Torgerson and Macpherson, 2011). Toxoplasma can be transmitted by variety of ways either horizontally or vertically, it was known by its capacity to invade wide range of cell types this is attributed to its invasive forms which called tachyzoites and bradyzoites that are related to the intermediate hosts and merozoites and sporozoites that are related to the definitive hosts (Ferguson and Dubremetz, 2013).

In animals, The disease may be ranged from asymptomatic infection as in cattle, horses and poultry species that are immunologically resistant (Jones and Dubey, 2012) to the serious disease which can be expressed as storms of abortions and prenatal deaths as in sheep (Dubey, 2008). Toxoplasmosis may also be fatal as in sea otters (Miller et al., 2008).

In human, Toxoplasma was known to infect 30-50 \% of the world's human population with great

Corresponding author: Dr. NOURHAN EISSA

E-mail address: vet_noura@yahoo.com

Present address: Department of Animal Hygiene and Zoonoses, Faculty of Veterinary Medicine, University of Sadat City, Egypt epidemiological variations among populations within different countries, different geographical areas in the same country and even among the different ethnic groups living in the same area (Deji-Agboola et al., 2011). Although most Toxoplasma infections are asymptomatic in immunocompetent adults, the disease expresses itself violently among immunocompromized individuals as causing acute life-threatening toxoplasmic encephalitis in the people who have HIV/AIDS and a T-cell count less than 100 cells/ $\mu \mathrm{L}$ (Weiss and Dubey, 2009). Sever infection also can occur in vertical transmission when the mother becomes infected for the first time during pregnancy causing sever congenital defects and also eye diseases that may end with permanent loss of vision (Olariu et al., 2011). Also, foodborne toxoplasmosis is considered a leading cause of death in the United States (Jones et al., 2014).

The diagnosis of the disease in animals and human is investigated by direct methods as polymerase chain reaction (PCR) since a single $T$. gondii parasite could be directly detected by PCR using the 35- fold repetitive $\mathrm{B} 1$ gene as a target for amplification (Wahab et al., 2010) and indirect methods as enzyme linked immunosorbent assay (ELISA) that is simple and rapid test that testing serum antibodies for large number of samples with the chosen anti-species conjugate (Naot and Remington, 2008). 
The aim of the current work was to perform a surveillance of toxoplasmosis among sheep to get an indication of their possible role in human toxoplasmosis, examination of some cattle raw milk samples by PCR technique to highlight their potential role in foodborne toxoplasmosis. We also aimed to determine the prevalence and the relevant risk factors of toxoplasmosis among women in Menoufia Governorate.

\section{MATERIALS AND METHODS}

\section{Specimen collection:}

A total of 50 adult sheep of Baladi breed (in contact with cats, soil and stream water) from 2 different localities in Menoufia Governorate (30 samples were collected from a sheep flock reared in Kafr Tanbidi while the other 20 samples were collected from a sheep flock in Shebein El Kom) in the period from June 2014 to April 2015. 50 sheep serum samples were examined by ELISA IgG as well as 50 sheep whole blood samples were examined by PCR technique for detecting Toxoplasma DNA. Moreover, a total of 31 cattle milk samples were collected from different dairy cows that were reared by different dairy farmers in different localities in Shebein El Kom, Menoufia Governorate in the period from March 2015 to May 2015 for advanced DNA diagnosis of Toxoplasma tachyzoites in milk.

Furthermore, a total of 250 serum samples were collected from women in the child bearing age (18 40 years) attended various clinic laboratories in Shebein El-Kom, Menoufia Governorate in the period from June 2014 to August 2015 for examination by ELISA IgG and ELISA IgM. Some of the potential risk factors were investigated by using a short questionnaire including age, occupation, residence, history of previous gestations, eating undercooked meat, ingestion of raw milk or milk products and contact with cat or with soil and the type of consumed water.

\section{Detection of anti-T. gondii IgG and IgM antibodies by ELISA assay:}

All samples of blood were collected and centrifuged at $3000 \mathrm{rpm}$ for $10 \mathrm{~min}$ and the separated serum was stored in labeled aliquots at $-20^{\circ} \mathrm{C}$ and examined for IgG and IgM antibodies According to El Gamal et al. (2013) by using commercial ELISA kits (Pishtaz Teb Zaman Diagnostics, Tehran, Iran). Further modification was carried during examination of sheep sera by Substitution of the Pishtaz IgG conjugate with another conjugate solution contains peroxidaselabeled affinity purified antibody to sheep $\operatorname{IgG}(\gamma)$ poly clonal antibody which was produced in rabbit (cat. no. 04-23-02, KPL, Inc., USA) that was used in dilution of $1: 100$ in a dilution buffer solution of $0.5 \%$ bovine serum albumin (BSA) in phosphate buffered saline solution (PBS) containing $0.05 \%$ tween. The simplest way to prepare a PBS solution is to use PBS buffer tablets of PH 7.4 (Medicago AB, Sweden) to give a ready-to-use PBS solution when dissoluted in a specified quantity of distilled water.

\section{Extraction of $\boldsymbol{T}$. gondii DNA:}

The blood samples of sheep and cattle milk samples were frozen at $-20^{\circ} \mathrm{C}$ till examination by PCR. DNA extraction from blood samples and milk samples was performed in accordance with the manufacturer's instructions of Biospin Whole Blood Genomic DNA Extraction Kit (catalog. no. BSC06S1, Bioflux Corporation, Arrow Plaza, Tokyo, Japan) and GspinTM Total DNA Extraction Kit (cat. no. IBTQMS-GT1704_R01-2012-01, intron biotechnology, Seoul, Korea), respectively.

\section{Amplification and detection of $T$. gondii DNA:}

The primers were used according to Rahdar et al. (2012) as follows: forward 5'AAAAATGTGGGAATGAAAGAG-3' and reverse 5'-ACGAATCAACGGAACTGTAAT-3'. The final volume of PCR reaction was set up in a $25 \mu \mathrm{l}$. Each PCR tube contained $10 \mu \mathrm{l}$ of master mix from (cat. no. 25027, Intron Biotechnology, Korea), $0.5 \mu \mathrm{l}$ of each primer, $10 \mu \mathrm{l}$ of distilled water, and $4 \mu \mathrm{l}$ of extracted DNA. In a thermal cycler model (GS1 Base Unit GS00001, USA), the cycling conditions were performed as denaturation at $95^{\circ} \mathrm{C}$ for $10 \mathrm{~min}$ followed by 35 cycles at $94^{\circ} \mathrm{C}$ for $1 \mathrm{~min}$, at $52^{\circ} \mathrm{C}$ for $45 \mathrm{sec}$ and at $72^{\circ} \mathrm{C}$ for $1 \mathrm{~min}$ for each cycle. The final cycle was followed by an extension step at $72^{\circ} \mathrm{C}$ for 10 min. A $10 \mu \mathrm{l}$ of each PCR product was subjected to gel electrophoresis in $2 \%$ agarose gel electrophoresis (cat. no. 35-1010, peQ Lab GmbH, Erlangen, Germany) with using GeneRuler ${ }^{\mathrm{TM}} 100 \mathrm{bp}$ plus DNA ladder (cat. no. SM0323, Thermo Scientific Inc., USA) as a marker. The expected PCR product size was $469 \mathrm{bp}$. RH strain of $T$. gondii which was used as positive control, was obtained kindly together with the primers from Animal Medicine and Infectious Diseases Department, Fac. of Vet. Med., Univ. of Sadat City.

\section{Statistical analysis:}

Data were analyzed using Chi- Square analysis test (X2) by using SPSS version 17 as was performed by Deji-Agboola et al. (2011). Sensitivity = true positives (TP) / [true positive (TP) + false negative $(\mathrm{FN})] \times 100$. Specificity $=$ true negatives $(\mathrm{TN}) /$ [true negative $(\mathrm{TN})+$ false positives $(\mathrm{FP})] \times 100$. Accuracy =number of correct results divided by the total number of results $\mathrm{x} 100$. Positive Predictive Value $(\mathrm{PPV})=$ true positive $(\mathrm{TP}) /[$ true positive $(\mathrm{TP})+$ false positive (FP)] x100. Negative Predictive Value $(\mathrm{NPV})=$ true negatives $(\mathrm{TN}) /$ [true negatives $(\mathrm{TN})$ + false negatives (FN)] x100. 


\section{RESULTS}

Table 1: Detection of anti-T. gondii IgG antibodies and Toxoplasma DNA in sheep in relation to areas of collection by using ELISA IgG and PCR:

\begin{tabular}{|c|c|c|c|c|}
\hline \multirow{2}{*}{ Area of collection } & \multicolumn{2}{|c|}{ Positive ELISA IgG } & \multicolumn{2}{|c|}{ Positive PCR } \\
\hline & No. & $\%$ & No. & $\%$ \\
\hline Kafr Tanbidi (No.= 30) & 20 & 66.67 & 6 & 20 \\
\hline Shebein El Kom $($ No.=20) & 10 & 50 & 5 & 25 \\
\hline Total $($ No. $=50)$ & 30 & 60 & 11 & 22 \\
\hline Chi- square & $1.39^{\mathrm{NS}}$ & & $0.18^{\Gamma}$ & \\
\hline P-value & 0.24 & & 0.68 & \\
\hline
\end{tabular}

NS Non Significant

Table 2: Results and accuracy of ELISA IgG in comparison with PCR among the examined sheep:

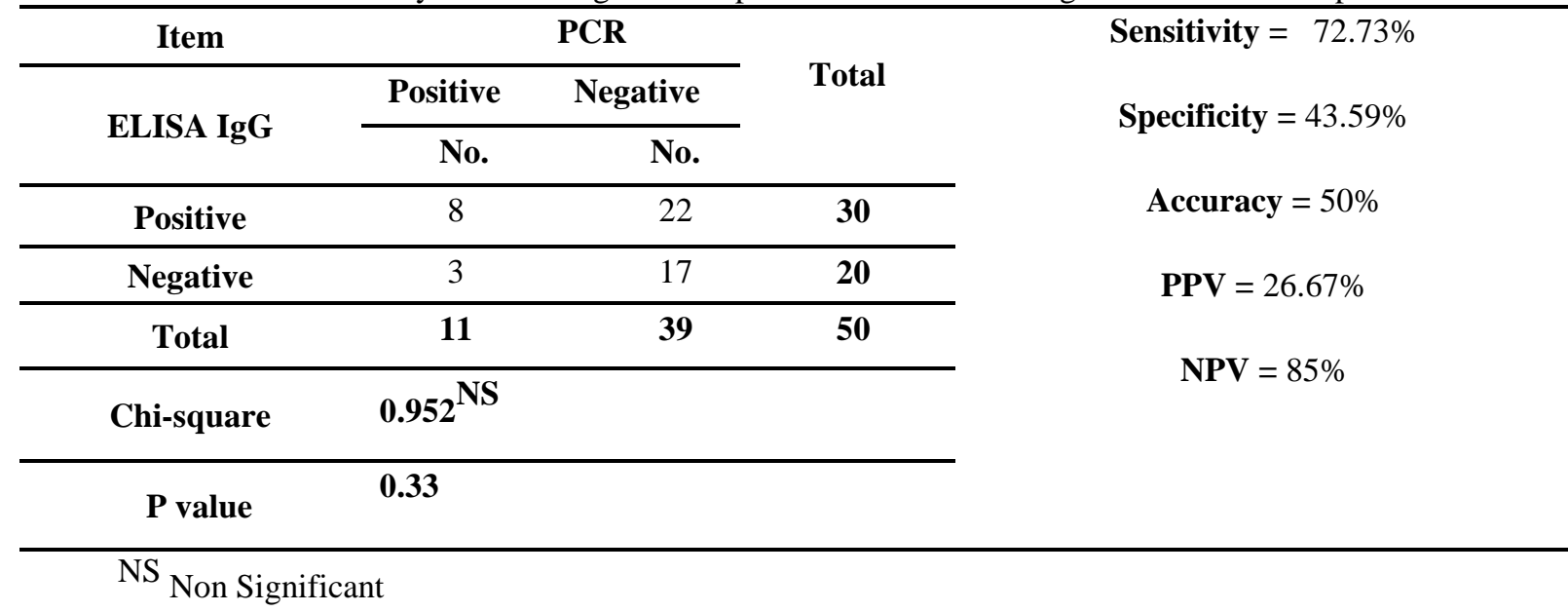

Table 3: Molecular detection of $T$. gondii DNA among the examined cattle milk samples by using PCR.

\begin{tabular}{cccccc}
\hline & & \multicolumn{3}{c}{ Positive } & \multicolumn{2}{c}{ Negative } \\
\cline { 3 - 5 } Test & No. tested & No. & \% & No. & \% \\
\cline { 3 - 6 } PCR & $\mathbf{3 1}$ & 6 & 19.35 & 25 & 80.65 \\
\hline
\end{tabular}

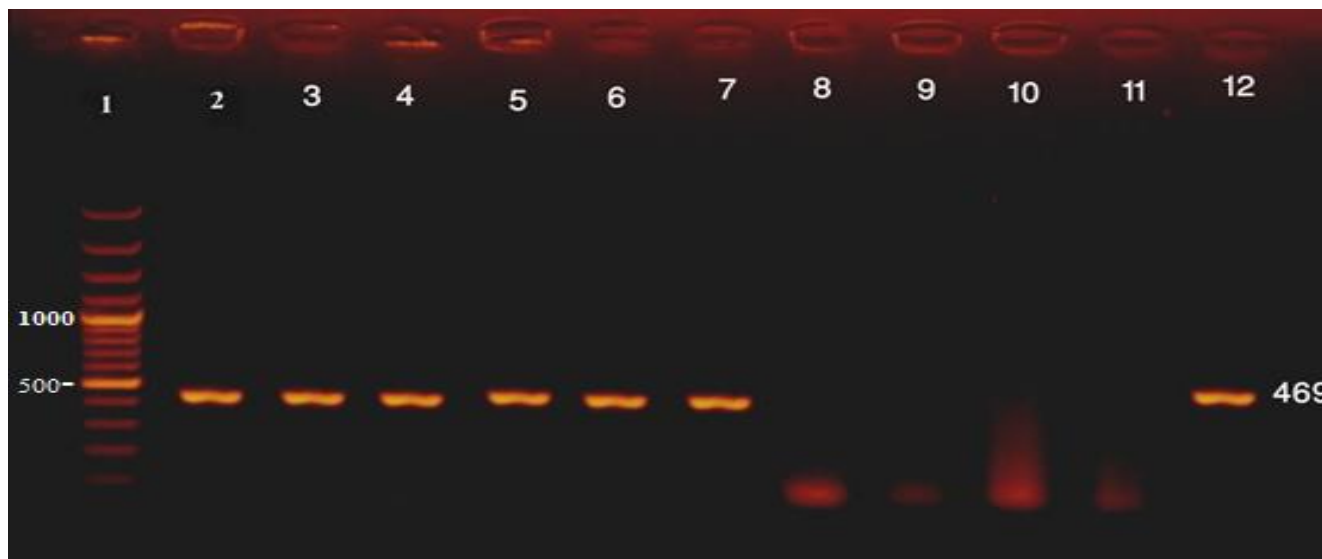

Figure (1): Ethidium bromide-stained agarose gel electrophoresis showing results of PCR amplification of $B 1$ gene of T. gondii in whole sheep blood and cattle milk. Lane 1: DNA ladder, lane 2, 3 and 4: milk positive results, lane 5, 6 and 7: blood positive results, lane 8, 9, 10: negative results, lane 11: negative control and lane 12: positive control. 
Table 4: Seroprevalence of anti-T. gondii $\operatorname{IgG}$ and IgM antibodies in the tested women by ELISA test.

\begin{tabular}{ccccc}
\multirow{2}{*}{ No. tested } & \multicolumn{3}{c}{ Positive IgG } & \multicolumn{2}{c}{ Positive IgM } \\
\cline { 2 - 5 } & No. & \% & No. & \% \\
\hline $\mathbf{2 5 0}$ & 136 & 54.4 & 21 & 8.4 \\
\hline
\end{tabular}

Table 5: Seroprevalence of anti-T. gondii $\operatorname{IgG}$ antibodies in relation to demographic data, relevant obstetric history and risk factors:

\begin{tabular}{|c|c|c|c|c|c|c|}
\hline \multirow[t]{2}{*}{ Variables } & \multicolumn{2}{|c|}{ Positive IgG } & \multicolumn{2}{|c|}{ Negative IgG } & \multirow{2}{*}{$\begin{array}{c}\text { Chi- } \\
\text { square }\end{array}$} & \multirow{2}{*}{$\begin{array}{c}\text { P- } \\
\text { value }\end{array}$} \\
\hline & No. & $\%$ & No. & $\%$ & & \\
\hline $\begin{array}{ll}\text { Age groups: } \\
\begin{array}{cl}- & \geq 20(\text { No. }=25) \\
- & 21-24(\text { No. }=103) \\
- & 25-28(\text { No. }=61) \\
- & 29-32(\text { No. }=33) \\
- & 33-36(\text { No. }=20) \\
- & 37-40(\text { No. }=8)\end{array}\end{array}$ & $\begin{array}{l}15 \\
59 \\
26 \\
14 \\
16 \\
6\end{array}$ & $\begin{array}{c}60 \\
57.28 \\
42.6 \\
42.42 \\
80 \\
75\end{array}$ & $\begin{array}{c}10 \\
44 \\
35 \\
19 \\
4 \\
2\end{array}$ & $\begin{array}{l}40 \\
42.72 \\
57.38 \\
57.38 \\
20 \\
25\end{array}$ & $12.63^{*}$ & 0.027 \\
\hline 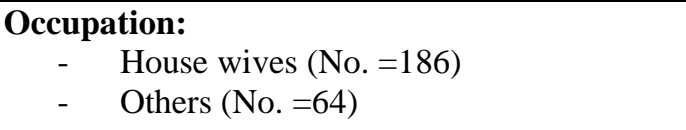 & $\begin{array}{c}105 \\
31\end{array}$ & $\begin{array}{l}56.45 \\
48.44\end{array}$ & $\begin{array}{l}81 \\
33\end{array}$ & $\begin{array}{l}43.55 \\
51.56\end{array}$ & $1.23 \mathrm{NS}$ & 0.27 \\
\hline \begin{tabular}{ll}
\multicolumn{2}{l}{ Residence: } \\
$-\quad$ Rural $($ No. $=137)$ \\
$-\quad$ Urban (No. $=113)$
\end{tabular} & $\begin{array}{l}75 \\
61\end{array}$ & $\begin{array}{l}54.74 \\
53.98\end{array}$ & $\begin{array}{l}62 \\
52\end{array}$ & $\begin{array}{l}45.26 \\
46.02\end{array}$ & $0.015^{\mathrm{NS}}$ & 0.90 \\
\hline $\begin{array}{cl}\text { Prevailing climatic conditions: } \\
-\quad \text { Warm conditions (No. }=111) \\
-\quad \text { Cold conditions (No. }=139)\end{array}$ & $\begin{array}{l}72 \\
64\end{array}$ & $\begin{array}{l}64.86 \\
46.04\end{array}$ & $\begin{array}{l}39 \\
75\end{array}$ & $\begin{array}{l}35.14 \\
53.96\end{array}$ & $8.81^{* *}$ & 0.003 \\
\hline $\begin{array}{l}\text { Gravidity: } \\
-\quad \text { primi }(\text { No. }=200) \\
-\quad \text { multi }(\text { No. }=50)\end{array}$ & $\begin{array}{c}102 \\
34\end{array}$ & $\begin{array}{l}51 \\
68\end{array}$ & $\begin{array}{l}98 \\
16\end{array}$ & $\begin{array}{l}49 \\
32\end{array}$ & $4.66^{*}$ & 0.03 \\
\hline $\begin{array}{cc}\text { Abortion: } \\
-\quad \text { Recently aborted (No.=111) } \\
-\quad \text { Healthy pregnant (No.=139) }\end{array}$ & $\begin{array}{l}70 \\
66\end{array}$ & $\begin{array}{l}63.06 \\
47.48\end{array}$ & $\begin{array}{l}41 \\
73\end{array}$ & $\begin{array}{l}36.94 \\
52.52\end{array}$ & $6.04^{*}$ & 0.014 \\
\hline 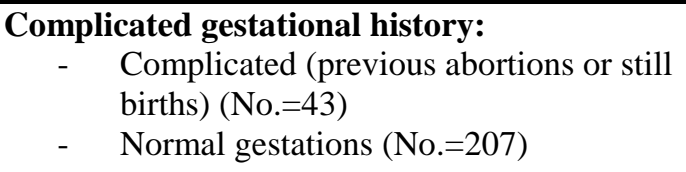 & 26 & $\begin{array}{l}60.47 \\
53.14\end{array}$ & $\begin{array}{l}17 \\
97\end{array}$ & $\begin{array}{l}39.53 \\
46.86\end{array}$ & $0.77^{\mathrm{NS}}$ & 0.38 \\
\hline $\begin{array}{cl}\text { Eating undercooked meat: } \\
-\quad \text { Consumers (No.=132) } \\
-\quad \text { Non consumers (No.=118) }\end{array}$ & $\begin{array}{l}81 \\
55\end{array}$ & $\begin{array}{l}61.36 \\
46.61\end{array}$ & $\begin{array}{l}51 \\
63\end{array}$ & $\begin{array}{l}38.64 \\
53.39\end{array}$ & $5.47^{* *}$ & 0.019 \\
\hline $\begin{aligned} \text { Drinking cow raw milk: } \\
-\quad \text { Consumers (No.=176) } \\
-\quad \text { Non consumers (No.=74) }\end{aligned}$ & $\begin{array}{c}105 \\
31\end{array}$ & $\begin{array}{c}59.66 \\
41.9\end{array}$ & $\begin{array}{l}71 \\
43\end{array}$ & $\begin{array}{l}40.34 \\
58.11\end{array}$ & $6.63^{* *}$ & 0.01 \\
\hline $\begin{array}{cl}\text { Cat contact: } \\
-\quad \text { Cat contactors (No.=78) } \\
-\quad \text { Non contactors (No.=172) } \\
\end{array}$ & $\begin{array}{l}51 \\
85 \\
\end{array}$ & $\begin{array}{c}65.4 \\
49.42 \\
\end{array}$ & $\begin{array}{l}27 \\
87 \\
\end{array}$ & $\begin{array}{l}34.62 \\
50.58 \\
\end{array}$ & $5.52^{*}$ & 0.019 \\
\hline $\begin{array}{cl}\text { Contact with soil: } \\
-\quad \text { Contactors }(\text { No. }=61) \\
-\quad \text { Non contactors }(\text { No. }=189)\end{array}$ & $\begin{array}{c}35 \\
101\end{array}$ & $\begin{array}{l}57.38 \\
53.44\end{array}$ & $\begin{array}{l}26 \\
88\end{array}$ & $\begin{array}{l}42.62 \\
46.56\end{array}$ & $0.288^{\mathrm{NS}}$ & 0.59 \\
\hline $\begin{array}{ll}\text { water consumed: } \\
-\quad \text { Filtered/treated tape water }(\text { No. }=222) \\
-\quad \text { wells water }(\text { No. }=28)\end{array}$ & $\begin{array}{c}115 \\
21\end{array}$ & $\begin{array}{c}51.80 \\
75\end{array}$ & $\begin{array}{c}107 \\
7\end{array}$ & $\begin{array}{c}48.20 \\
25\end{array}$ & $5.39^{*}$ & 0.02 \\
\hline
\end{tabular}


Table 6: Seroprevalence of anti-T. gondii IgM antibodies in relation to demographic data, relevant obstetric history and risk factors.

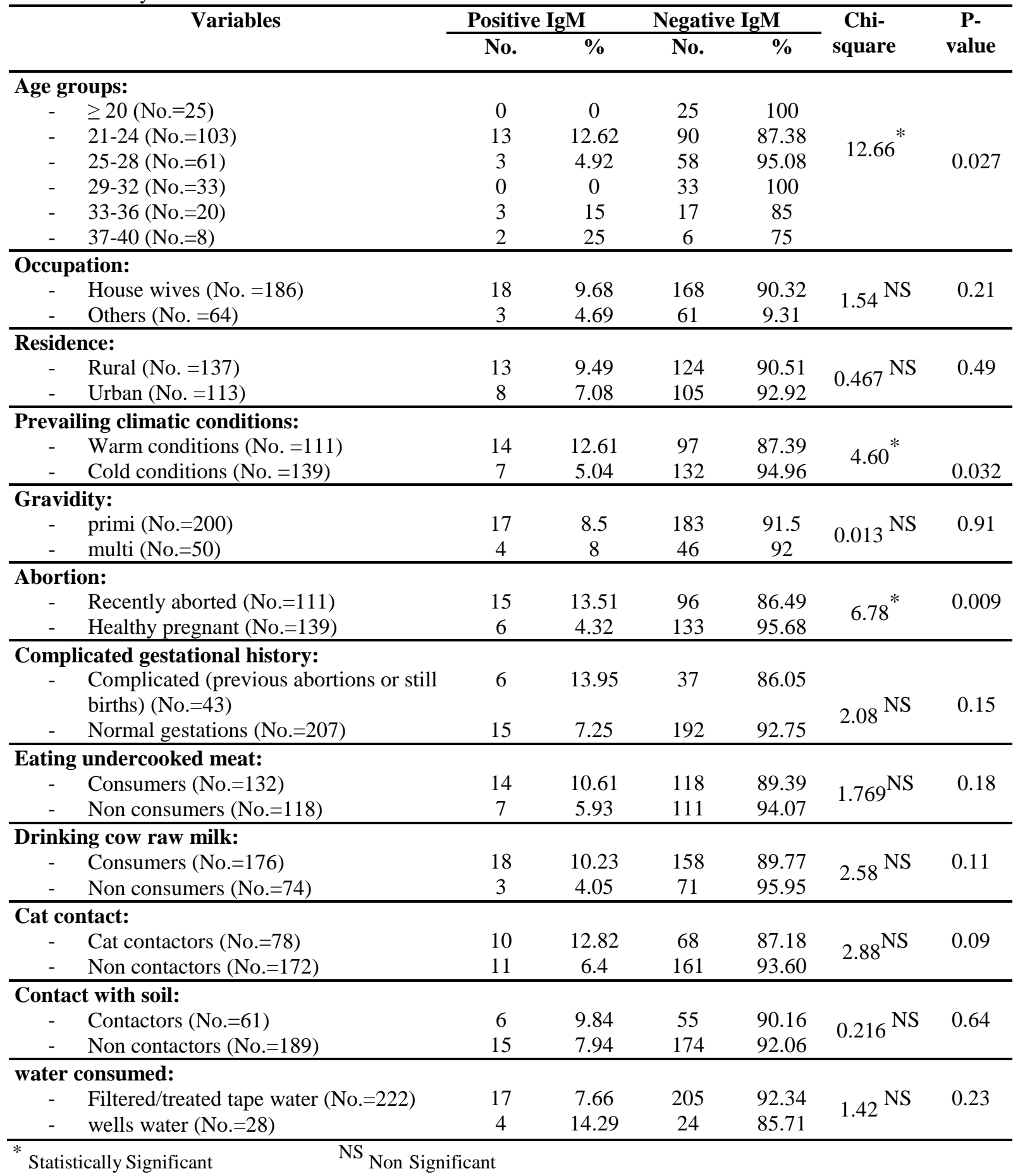

Table 7: Number of women with positive and negative ELISA IgG in relation to ELISA IgM results.

\begin{tabular}{cccc}
\hline \multirow{2}{*}{ Item } & Positive IgM & Negative IgM & Total \\
\cline { 2 - 4 } & No. & No. & $\mathbf{1 3 6}$ \\
\hline Positive IgG & 15 & 121 & $\mathbf{1 1 4}$ \\
\hline Negative IgG & 6 & 108 & $\mathbf{2 5 0}$ \\
\hline Total & $\mathbf{2 1}$ & $\mathbf{2 . 6 8}$ & \\
\hline Chi- square & & $\mathbf{0 . 1 0 2}$ & \\
\hline P- value & &
\end{tabular}

NS Non-Significant. 


\section{DISCUSSION}

The results presented in table (1) revealed that $60 \%$ of tested sheep was positive for IgG antibodies with $66.67 \%$ were positive in Kafr Tanbidi and $50 \%$ in Shebein El-Kom. The obtained result was in agreement with Bártová et al. (2009) who declared prevalence of $59 \%$ in Czech Republic in Central Europe and Hassanain et al. (2013) who showed a prevalence of $61.4 \%$ in a previous study performed at National Research Center (NRC) in Cairo Governorate, Egypt. On the other hand, higher IgG seropositivity was recorded $98.4 \%$ in El-Fayoum Governorate, Egypt and $71 \%$ in Grenada, West Indies by Ghoneim et al. (2009) and Sharma et al. (2015), respectively.

On the contrary, lower seropositivity rates were detected: $28.86 \%$ in the Delta region of Egypt (Mahboub et al., 2013) and 20\% in Central Ethiopia (Gebremedhin et al., 2014).

The high seroprevalence in the current study could be referred to the grazing pattern where the tested sheep flocks were grazed daily with a free access to contaminated feed and water, the high Toxoplasma seroprevalence in sheep confirms the environmental contamination of pastures and food during grazing with infective oocysts (Prelezov et al., 2008). In Egypt, Al-Kappany et al. (2010) reported that the Egyptian stray cats are very abundant and widely spread with $97.4 \%$ of them are Toxoplasma infected indicating the high risk of environmental contamination with sporulated oocysts that remain infective in soil and water for a long time. Younis et al. (2015) showed that toxoplasmosis increases with age of sheep and Mahboub et al. (2013) illustrated presence of a significant association between toxoplasmosis and the sheep breed, the highest seropositivity $35.42 \%$ was found among Baladi breeds in the Delta region of Egypt in comparison with $13.33 \%$ among Ossemi breeds, $21.43 \%$ among Rahmani breeds while not detected among Barki breeds.

It was no surprise that molecular detection of Toxoplasma DNA showed only $22 \%$ of sheep were PCR positive as PCR used to detect the parasite antigen while ELISA IgG used to detect the parasite antibody. From them $20 \%$ was PCR positive in Kafr Tanbidi and $25 \%$ was PCR positive in Shebein ElKom.

Concerning the comparison of ELISA IgG in relation to PCR (PCR technique was used as a standard test) that was illustrated in table (2), ELISA IgG detected ( 8 out of 11) positive PCR samples (true positive result) indicating chronic infection with the Toxoplasma antigen still in blood, while ELISA IgG could not detect (3 out of 11) positive PCR samples (false negative), which could be corresponding to a recent infection at the time of examination leading to insufficient production of $\mathrm{IgG}$. On the other side, ELISA IgG was able to detect (22 out of 39) negative PCR samples (false positive results) indicating chronic infection with no antigen in blood but only IgG specific antibodies are present. About 17 samples were negative by both ELISA IgG and PCR (true negative) indicating their susceptibility for acquiring recent infection.

Furthermore, the accuracy of ELISA IgG compared to PCR for diagnosis of toxoplasmosis in the tested sheep was evaluated. The calculated sensitivity (i.e. the probability that the assay will be positive when the infection is present) for ELISA IgG was $72.7 \%$, specificity (i.e. the probability that the assay will be negative when the infection is absent) was $43.59 \%$, PPV was $26.67 \%$, NPV was $85 \%$ and so the accuracy of ELISA IgG was $50 \%$ as compared with PCR. The obtained results were somewhat in agreement with the findings of El Gamal et al. (2013).

More attention should be given to raw milk and milk products as potential sources for human toxoplasmosis. Camossi et al. (2011) illustrated that the tachyzoites present in the milk of affected animals can be horizontally transmitted to offspring via consumption. Moreover, Spišák et al. (2010) confirmed experimentally that the survival of tachyzoites in milk occurs for 3-7 days at $4{ }^{\circ} \mathrm{C}$, proving the role of raw milk as a source of $T$. gondii infection.

The results tabulated in table (3) represented $19.35 \%$ of the examined milk samples were PCR positive. A previous molecular study was done on 889 raw milk samples from different species in Iran resulted in a positivity rate of $5.17 \%$ among the whole examined milk samples with a positivity rate of $3.5 \%$ among examined cattle milk itself (Dehkordi et al., 2013).

In Egypt, Ahmed et al. (2014) failed to detect any $T$. gondii DNA by PCR in raw cow milk in Sharkia Governorate. However, they concluded a significant association between toxoplasmosis in pregnant women and the consumption of raw cow milk and homemade cheese.

The considerable high positivity of $T$. gondii in cow's milk showed in the present study may be referred to many factors such as management and hygienic standards in breeding, abundance of stray cats which are in contact with herds and the humid climate and agricultural nature of collecting areas in Menoufia Governorate that favor survival of sporulated oocysts in soil and water, some farmers depend on wells and stream water for watering cows (infective oocysts can maintain their infectivity in water for long time) (Jones and Dubey, 2010). Moreover, the considerable high seropositivity rate of Toxoplasma specific antibodies detected among sheep in the current study 
are in accordance with the increasing positivity rate among tested cattle selected from the same areas (Boughattas et al., 2014).

Available investigations on the epidemiology of Toxoplasma in cattle milk are not enough in Egypt, although previous studies were done to detect Toxoplasma antibodies in cows in Egypt and other parts of the world but the current study is considered the first Egyptian study detected $T$. gondii DNA in cattle raw milk so, we recommend intensifying the studies on this part.

The seroprevalence of anti- $T$. gondii $\mathrm{IgG}$ antibodies in the tested women by ELISA was shown $54.4 \%$ in table (4). The obtained result was in agreement with the Egyptian researchers Nassef et al. (2015) and Shehata et al. (2016) who reported seropositivity of IgG antibodies $52.2 \%$ and $50 \%$ in a previous study in Menoufia Governorate and Alexandria Governorate, respectively. Moreover it agrees with results of other parts of the world as: $50.6 \%$ in Morocco (El Mansouri et al., 2007), 51.4\% in Saudi Arabia (Al Mohammad et al., 2010) and 56.2\% in Iran (Sharif et al., 2016).

On the other hand, relatively higher rates were documented in Egypt as: $67.5 \%$ in Menoufia Governorate by El Deeb et al. (2012), 62\% in Sharkia Governorate by El Gamal et al. (2013). Another high rate $81.4 \%$ was also detected in Central Ethiopia (Gebremedhin et al., 2013).

On the contrary in Egypt, lower seroprevalence rates were illustrated in different Governorates as: $35.2 \%$ in Beni-Suef (Aboelhadid et al., 2013), 46.1\% in Qena Governorate (Tammam et al., 2013) and $44 \%$ in Dakhalia Governorate (El-Tantawy et al., 2014). Moreover, lower rates were shown in other parts of the world as: $9.35 \%$ in Italy (Tomasoni et al., 2010), $44.8 \%$ among pregnant women in Libya (Mousa et al., 2011) and 6.4\% among pregnant women in South Africa (Kistiah et al., 2012). The high IgG antibodies prevalence reflects the chronic Toxoplasma infection (Remington et al., 2004).

Moreover, the seroprevalence of $\operatorname{IgM}$ specific antibodies was $8.4 \%$ that was in agreement with those of some Egyptian investigators who reported IgM rates of $9.78 \%$ and $10 \%$ at Sharkia and Menoufia Governorates by Abd El-Ghany and Amin (2012) and Nassef et al. (2015), respectively. Moreover in Ethiopia a seroprevalence rate $8.98 \%$ was noticed by Tilahun et al. (2016).

On the contrary, relatively higher rates were detected in some Egyptian Governorates as: $60 \%$ in Dakahlia Governorate (Soliman et al., 2001), 47\% in Sharkia Governorate (El Gamal et al., 2013) and 18\% in Qena Governorate (Tammam et al., 2013). Moreover, higher prevalence rates were declared in other parts of the world as: $45.89 \%$ in Italy (De Paschale et al., 2008) and $46 \%$ in Tanzania (Swai and Schoonman, 2009).

On the other hand, a low IgM seroprevalence rate $2.8 \%$ was recorded in Menoufia Governorate by El Deeb et al. (2012) that still greatly different from the very low rate $0.8 \%$ which had been reported in Nigeria by Ishaku et al. (2009). The importance of IgM positivity is that it indicates presence of a recently acquired infection (Goldstein et al., 2008).

The worldwide variation in seroprevalence of anti- $T$. gondii $\operatorname{IgG}$ and $\operatorname{IgM}$ specific antibodies from one geographic area to another occurs relating to the environmental and socioeconomic conditions, including eating habits, general level of hygiene, host susceptibility, geographical location and humidity of the soil (Furtado et al., 2011).

Tables (5) and (6) revealed seroprevalence of anti- $T$. gondii $\operatorname{IgG}$ and $\operatorname{IgM}$ antibodies respectively, in relation to demographic data, relevant obestitric history and risk factors, regarding to age, it was noticed that the majority of positive IgG percentage was $80 \%$ at age group (33-36 years) followed by $75 \%$ at age group (37-40 years) while the majority of positive IgM percentage was $25 \%$ at age group (3740 years) followed by $15 \%$ at age group (33-36 years). Ayi et al. (2009) and Deji-Agboola et al. (2011) failed to find any association between women age and Toxoplasma prevalence. The prevalence of Toxoplasma specific antibodies increases with age in accordance with increasing exposure to sources of infection during life.

The present study failed to find any significant association between toxoplasmosis and neither occupation nor residence in accordance with Flatt and Shetty (2012); Kamal et al. (2015) and Nassef et al. (2015). Concerning to women occupation, seroprevalence was $56.45 \%$ by ELISA IgG and $9.68 \%$ by ELISA IgM for housewives while was $48.44 \%$ and $4.69 \%$ for women with other occupations by ELISA IgG and ELISA IgM, respectively.

The high seroprevalence rate among house wives can be explained as they spend more time cooking at home handling raw meat, handling pet animals including cats at home and manipulating with dust or dirt during frequent home cleaning. Furthermore, working women with higher socioeconomic standers, higher education levels are adopted for the appropriate hygienic measures regarding food and cooking habits which tend to eradicate the sources of disease transmission. Ayi et al. (2009) reported that Toxoplasma infection through handling of raw meat cannot be ruled out since penetration of tachyzoites through broken skin has been reported in some countries. 
As regards to residence, $54.74 \%$ of women residing rural areas were $\operatorname{IgG}$ positive and $9.49 \%$ were $\operatorname{IgM}$ positive while seroprevalence was $53.98 \%$ and $7.08 \%$ for women residing urban areas by ELISA IgG and ELISA IgM, respectively. The insignificant relationship between residing and acquiring Toxoplasma antibodies in the current study might be referred to the fact of urbanization with absence of rural life style within Egypt as a whole. As well, individuals residing urban areas in Menoufia Governorate had more opportunities of acquiring toxoplasmosis by several routes rather than contact with soil and farm animals or watering from wells (the main sources of infection among rural residing women), they could acquire infection by frequent cleaning litter boxes of indoor infected cats, eating contaminated undercooked meat outside in restaurants, the wide preference of Menoufia individuals to consume organic raw milk and milk products (as: Karish cheese).

A significant association was shown between prevailing climatic conditions and increasing Toxoplasma prevalence in agreement with Dehkordi et al. (2013). The seropositivity in women was $64.86 \%$ and $12.61 \%$ in warm climate while was $46.04 \%$ and $5 \%$ in cold climate by using ELISA IgG and ELISA IgM, respectively. Toxoplasma sporulated oocysts are able to remain infective in warm, humid soil (that distinguishes the climate of Menoufia Governorate) and do not survive in dried, cold climates (Robert-Gangneux and Dardé, 2012).

According to obstetric history of the examined women, a significant association was found between increasing $\mathrm{IgG}$ seroprevalence and increasing gravidity and presence of abortion in accordance with Flatt and Shetty (2012) and Nassef et al. (2015), our obtained result was referred to suppressed immune response or hormonal imbalance among multigravida women as well as increasing in pregnancies is mainly associated with age increase. Moreover, persistence of Toxoplasma cysts in chronically infected uteri with their rupture during placentation infects the fetus in the first trimester of pregnancy causing recurrent abortions (Malik et al., 2014) while it was failed to find any significant statistical association with presence of complicated gestational history in agreement with Babaie et al. (2013).

On the other side, the current work documented no significant relationship between IgM seroprevalenc and neither gravididity nor presence of complicated gestational history in accordance with RobertGangneux and Dardé (2012). However, a statistical significant relationship was detected between $\operatorname{IgM}$ prevalence and abortion that was referred to the fact that recent Toxoplasma infection is accompanied with presence of tachyzoites circulating in blood that can distribute in all body fluids and pass the placental barrier infecting the fetus in the first trimester of pregnancy causing miscarriage or other congenital defects (Reis et al., 2006) the obtained result was on the contrary with findings of Deji-Agboola et al. (2011).

Concerning the behavioral risk factors, a significant association was found between $\mathrm{IgG}$ seroprevalence and contact with cats in accordance with Nassef et al. (2015) while Abd El-Ghany and Amin (2012) and Kamal et al. (2015) failed to find any association between toxoplasmosis and cat contact. Exposure to cats' faeces via owning cat(s) or having cats in the immediate surrounding with handling cats' sandboxes containing their faeces was found to be associated with Toxoplasma infection (Al-Kappany et al., 2010).

Moreover, a significant association was found between IgG seroprevalence and consumption of raw cow milk in agreement with Ahmed et al. (2014) in accordance with the fact that tachyzoites in the milk can survive for a week at refrigerator (Spišák et al., 2010). A significant association was also found between $\mathrm{IgG}$ seroprevalence and eating undercooked meat in accordance of Abd El-Ghany and Amin (2012) and Kamal et al. (2015) because of the habit of eating some Egyptian food containing undercooked meat as: kabbab, shawarma, Hawawshy, Basterma and luncheon) that contain Toxoplasma encysted form which mainly present in skeletal muscles, brain, heart and visceral organs as: lungs, liver and kidneys (Skariah et al., 2010). On the other hand, Moura et al. (2013) failed to find any association between toxoplasmosis and consumption of neither raw cow milk nor undercooked meat.

Furthermore, a significant association was also found between IgG seroprevalence and drinking water from wells in agreement with findings of Moura et al. (2013). Contaminated water was previously recorded as the main cause of Toxoplasma outbreaks among humans in Canada and USA (Jones and Dubey, 2010).

The current study did not found any significant statistical association between increasing prevalence of IgG antibodies and soil contact unlike the findings of Deji-Agboola et al. (2011) and Nassef et al. (2015). Soil contact has many forms as farming, gardening, removing cat feces or even ingestion of crops directly from soil without washing.

On the other side, no significant association was able to be demonstrated between IgM seroprevalence and any of the studied behavioral risk factors in agreement with Deji-Agboola et al. (2011) and Nassef et al. (2015).

Table (7) declared the number of women with positive and negative ELISA IgG in relation to ELISA IgM results, 108 of the examined women were negative for both $\operatorname{IgG}$ and $\operatorname{IgM}$ antibodies 
indicating their susceptibility for primary infection through exposure to risk factors with the risk of vertical transmission of infection to fetus if they became infected for the first time during pregnancy and causing serious sequelae. On the other hand, 15 of women were positive for both $\operatorname{IgG}$ and $\operatorname{IgM}$ antibodies indicating sub-acute Toxoplasma infection or as acutely infected $<1$ year since IgM antibodies could be detected early in acute infection and might remain for short periods. 121 women were immune to Toxoplasma infection ( $\mathrm{IgG}+/ \mathrm{IgM}-)$ as prevalence of chronic infection for $>1$ year while 6 of tested women were possibly considered in early acute infection (IgG-/IgM+) (Robert-Gangneux and Dardé, 2012).

\section{REFERENCES}

Abd El-Ghany, A.M. and Amin, M.A. (2012): Epidemiology and Molecular Detection of Zoonotic T. gondii in Cat Feces and Seroprevalence of Anti-T. gondii Antibodies in Pregnant Women and Sheep. Life Sci. J., 9(1): 133-146.

Aboelhadid, S.M.; Abdel-Ghany, A.E.; Ibrahim, M.A. and Mahran, H.A. (2013): Seroprevalence of T. gondii infection in chickens and humans in Beni Suef, Egypt. Global Vet., 11(2): 139-44.

Ahmed, H.A.; Shafik, S.M.; Ali, M.E.; Elghamry, S.T. and Ahmed, A.A. (2014): Molecular detection of $T$. gondii DNA in milk and risk factors analysis of seroprevalence in pregnant women at Sharkia, Egypt. Vet. World, 7: 594-600.

Al-Kappany, Y.M.; Rajendran, C.; Ferreira, L.R.; Kwok, O.C.; Abu-Elwafa, S.A.; Hilali, M. and Dubey, J.P. (2010): High prevalence of toxoplasmosis in cats from Egypt: isolation of viable $T$. gondii, tissue distribution, and isolate designation. J. Parasitol., 96(6): 1115-8.

Al-Mohammad, H.I.; Amin, T.T.; Balaha, M.H. and Al-Moghannum, M.S. (2010): Toxoplasmosis among the pregnant women attending a Saudi maternity hospital: seroprevalence and possible risk factors. Ann. Trop. Med. Parasitol., 104(6): 493-504.

Ayi, I.; Edu, S.A.; Apea-Kubi, K.A.; Boamah, D.; Bosompem, K.M. and Edoh, D. (2009): Seroepidemiology of toxoplasmosis amongst pregnant women in the greater Accra region of Ghana. Ghana Med. J., 43(3): 107-14.

Babaie, J.; Amiri, S.; Mostafavi, E.; Hassan, N.; Lotfi, P.; Ahmad Reza Rastaghi, A.R. and Golkar, M. (2013): Seroprevalence and risk factors for $T$. gondii infection among pregnant women in Northeast Iran. Clin. Vaccine Immunol., 20(11): 1771-3.

Bártová, E.; Sedlák, K. and Literák, I. (2009): T. gondii and Neospora caninum antibodies in sheep in the Czech Republic. Vet. Parasitol., 161(1-2): 131-2.

Boughattas, S.; Ayari, K.; Sa, T.; Aoun, K. and Bouratbine, A. (2014): Survey of the Parasite
T. gondii in Human Consumed Ovine Meat in Tunis City. PLOS., 9(1): e85044.

Camossi, L.G.; Greca-Júnior, H.; Corrêa, A.P.; Richini-Pereira, V.B.; Silva, R.C.; Da Silva, A.V. and Langoni, H. (2011): Detection of T. gondii DNA in the milk of naturally infected ewes. Vet. Parasitol., 177(3-4): 256-61.

De Paschale, M.; Belvisi, C.; Cagnin, D.; Cerulli, T.; Clerici, P.; Mirri, P.; Manco, M.T.; Cavallari, S. and Viganò, E. F. (2008): Revision of the positive predictive value of IgM anti-Toxoplasma antibodies as an index of recent infection. New Microbiol., 31(1): 105-11.

Dehkordi, F.S.; Rahimi, E. and Abdizadih, R. (2013): Detection of $T$. gondii in raw caprine, ovine, buffalo, bovine, and camel milk using cell cultivation, cat bioassay, capture ELISA, and PCR methods in Iran. Foodborne Pathog. Dis., 10(2): 120-125.

Deji-Agboola, A.M.; Busari, O.S.; Osinupebi, O.A. and Amoo, A.O. (2011): Seroprevalence of $T$. gondii Antibodies among Pregnant Women Attending Antenatal Clinic of Federal Medical Center, Lagos, Nigeria. Int. J. Biol. Med. Res., 2(4): 1135-9.

Dubey, J.P. (2008): Refinement of pepsin digestion method for isolation of $T$. gondii from infected tissues. Vet. Parasitol. J., 74(1): 75-77.

El Deeb, H.K.; Salah-Eldin, H.; Khodeer, S. and Abd Allah, A. (2012): Prevalence of $T$. gondii infection in antenatal population in Menoufia governorate, Egypt. Acta. Trop., 124(3): 185191.

El Gamal, R.L.; Selim, M.A.; Mohamed, S.M.; Fathy, G.M. and Abdel Rahman, S.A. (2013): Comparison of PCR with ELISA in Diagnosis of recent Toxoplasmosis in Pregnant women. J. Am. Sci., 9(12): 824-832.

El Mansouri, B.; Rhajaoui, M.; Sebti, F.; Amarir, F.; Laboudi, M.; Bchitou, R.; Hamad, M. and Lyagoubi, M. (2007): Seroprevalence of toxoplasmosis in pregnant women Rabat, Morocco. Bull Soc. Pathol. Exot., 100(4): 28990.

El-Tantawy, N.; Taman, A. and Shalaby, H. (2014): Toxoplasmosis and Female Infertility: Is there a Co-Relation? American. J. Epidemiol. Infect. Dis., 2(1): 29-32.

Ferguson, D.J. and Dubremetz, J.F. (2013): The ultrastructure of $T$. gondii. In: Weiss, L. M. and Kim, K. (Eds.). T. gondii, the Model Apicomplexan: Perspectives and Methods (2nd ed.), Academic Press, London, UK, P: 19-48.

Flatt, A. and Shetty, N. (2012): Seroprevalence and risk factors for toxoplasmosis among antenatal women in London: a re-examination of risk in an ethnically diverse population. Euro. J. Public Health, 23(4): 648-652. 
Furtado, J.M.; Smith, J.R.; Belfort, R.; Gattey, D. and Winthrop, K.L. (2011): Toxoplasmosis: A Global Threat. J. Glob. Infect. Dis., 3(3): 281284.

Gebremedhin, E.Z.; Abebe, A.H.; Tessema, T.S.; Tullu, K.D.; Medhin, G.; Vitale, M.; Di Marco, V.; Cox, E. and Dorny, P. (2013): Seroepidemiology of $T$. gondii infection in women of child-bearing age in central Ethiopia. BMC Infect. Dis., 13(1): 101.

Gebremedhin, E.Z.; Abdurahaman, M.; Hadush, T. and Tessema, T.S. (2014): Seroprevalence and risk factors of $T$. gondii infection in sheep and goats slaughtered for human consumption in Central Ethiopia. BMC Research Notes, 7(1): 696.

Ghoneim, N.H.; Shalaby, S.I.; Hassanain, N.A.; Zeedan, G.S.; Soliman, Y.A. and Abdalhamed, A.M. (2009): Detection of genomic T. gondii DNA and anti-Toxoplasma antibodies in high risk women and contact animals. Global Veterinaria, 3(5): 395-400.

Goldstein, E.J.; Montoya, J.G. and Remington, J.S. (2008): Management of T. gondii Infection during Pregnancy. Clin. Infect. Dis., 47 (4): 554-66.

Hassanain, M.A.; El-Fadaly, H.A.; Hassanain, N.A.; Shaapan, R.M.; Barakat, A.M. and AbdElRazik, K.A. (2013): Serological and Molecular Diagnosis of Toxoplasmosis in Human and Animals. World J. Med. Sci., 9(4): 243-247.

Ishaku, B.S.; Ajogi, I.; Umoh, J.U.; Lawal, I. and Randawa, A.J. (2009): Seroprevalence and risk factors for $T$. gondii infection among antenatal women in Zaria, Nigeria. Res. J. Med. Med. Sci., 4(2): 483-8.

Jones, J.L. and Dubey, J.P. (2010): Waterborne toxoplasmosis - Recent developments. Experi. Parasitol., 124(1): 10-25.

Jones, J.L. and Dubey, J.P. (2012): Foodborne toxoplasmosis. Clin. Infect. Dis., 55(6): 845851.

Jones, J.L.; Parise, M.E. and Fiore, A.E. (2014): Neglected Parasitic Infections in the United States: Toxoplasmosis. Am. J. Trop. Med., 90(5): 794-799.

Kamal, A.M.; Ahmed, A.K.; Abdellatif, M.Z.; Tawfik, M. and Hassan, E.E. (2015): Seropositivity of Toxoplasmosis in Pregnant Women by ELISA at Minia University Hospital, Egypt. Korean J. Parasitol., 53(5): 605-610.

Kistiah, K.; Frean, J.; Winiecka-Krusnell, J. and Barragan, A. (2012): Unexpectedly low seroprevalence of toxoplasmosis in South Africa, Onderstepoort. J. Vet. Res., 79(2): 486.

Mahboub, H.D.; Helal, M.A.; Abd Eldaim, M.A.; Abd El-Razek, E.M. and Elsify, A.M. (2013): Seroprevalence of Abortion Causing Agents in Egyptian Sheep and Goat Breeds and Their Effects on the Animal's Performance. Journal of Agricultural Science, 5(9): 92-101.
Malik, A.; Rizvi, M.; Khan, F.; Khan, N.; Rabbani, T. and Khan, H.M. (2014): T. gondii in women with bad obstetric history and infertility: a five-year study. As. Pacific J. Trop. Dis., 4(1): S236-S9.

Miller, M.A.; Miller, W.A.; Conrad, P.A.; James, E.R.; Melli, A.C.; Leutenegger, C.M.; Dabritz, H.A.; Packham, A.E.; Paradies, D.; Harris, M.; Ames, J.; Jessup, D.A.; Worcestor, K. and Grigg, M.E. (2008): Type X T. gondii in a wild mussel and terrestrial carnivores from coastal California: new linkages between terrestrial mammals, runoff and toxoplasmosis of sea otters. Inter. J. Parasitol, 38(11): 13191328.

Moura, F.L.; Amendoeira, M.R.; Bastos, O.M.; Mattos, D.P.; Fonseca, A.B.; Nicolau, J.L.; Neves, L.B. and Millar, P.R.(2013): Prevalence and risk factors for $T$. gondii infection among pregnant and postpartum women attended at public healthcare facilities in the City of Niterói, State of Rio de Janeiro, Brazil. Rev. Soc. Bras. Med. Trop., 46(2): 2007.

Mousa, D.A.; Mohammad, M.A. and Tobol, A.B. (2011): T. gondii infection in pregnant women with previous adverse pregnancy outcome. Med. J. Islamic World Acad. Sci., 19(2): 95102.

Naot, Y. and Remington, J.S. (2008): An enzymelinked immunosorbent assay for detection of IgM antibodies to T. gondii: use for diagnosis of acute acquired toxoplasmosis. J. Infect. Dis., 142(5): 757-766.

Nassef, N.E.; Abd El-Ghaffar, M.M.; El-Nahas, N.S.; Hassanain, M.A.; Shams El-Din, S.A. and Ammar, A.I. (2015): Seroprevalence and genotyping of $T$. gondii in Menoufia governorate. Menoufia Medical J., 28(3): 617626.

Olariu, T.R.; Remington, J.S.; McLeod, R.; Alam, A. and Montoya, J.G. (2011): Severe congenital toxoplasmosis in the United States: clinical and serologic findings in untreated infants. Pediatr. Infect. Dis. J., 30(12): 1056-1061.

Prelezov, P.; Koinarski, V. and Georgieva, D. (2008): Seroprevalence of $T$. gondii infection among sheep and goats in the Stara Zagora region. Bulgarian J. Vet. Med., 11(2): 113-19.

Rahdar, M.; Samarbaf-Zadeh, A.R. and Arab, L. (2012): Evaluating the Prevalence of T. gondii in Meat and Meat Products in Ahvaz by PCR Method. Jundishapur J. Microbiol., 5(4): 570573.

Reis, M.M.; Tessaro, M.M. and DAzevedo, P.A. (2006): Toxoplasma IgM and IgG avidity in single samples from areas with high infection rate can determine the risk of mother-to-child transmission. Rev. Inst. Med. Trop., 48(2): 9398. 
Remington, J.S.; Thulliez, P. and Montoya, J.G. (2004): Recent developments for diagnosis of toxoplasmosis. J. Clin. Microbiol., 42(3): 941945.

Robert-Gangneux, F. and Dardé, M. (2012): Epidemiology of and Diagnostic Strategies for Toxoplasmosis. Clin. Microbiol. Rev., 25(2): 264-296.

Sharif, M.; Daryani, A.; Ebrahimnejad, Z.; Gholami, S.; Ahmadpour, E.; Borhani, S. and Lamsechi, N. (2016): Seroprevalence of anti-Toxoplasma IgG and IgM among individuals who were referred to medical laboratories in Mazandaran province, northern Iran., 9(1): 75-80.

Sharma, R.N.; Bush, J.; Tiwari, K.; Chikweto, A. and Bhaiyat, M.I. (2015): Seroprevalence of $T$. gondii in sheep and goats in Grenada, West Indies. Int. J. Curr. Res. Aca. Rev., 3(10): 262267.

Shehata, A.I.; Hassanein, F.I. and Abdul-Ghani, R. (2016): Seroprevalence of T. gondii infection among patients with non-schizophrenic neurodevelopmental disorders in Alexandria, Egypt. Acta Trop., 154: 155-9.

Skariah, S.; Mc-Intyre, M.K. and Mordue, D.G. (2010): T. gondii: determinants of tachyzoite to bradyzoite conversion. Parasitol Res., 107(2): 253-260.

Soliman, M.; Nour-Eldin, M.S.; Elnaggar, H.M.; ElGhareb, M.E. and Ramadan, N.I. (2001): Toxoplasma antibodies in normal and complicated pregnancy. J. Egypt Soc. Parasitol., 31(2): 637-46.

Spišák, F.; Turčeková, L.; Reiterová, K.; Špilovská, S. and Dubinský, P. (2010): Prevalence estimation and genotypization of $T$. gondii in goats. Biologia, 65(4): 670-674.

Swai, E.S. and Schoonman, L. (2009): Seroprevalence of $T$. gondii infection amongst residents of
Tanga district in Northeast Tanzania. Tanzan. J. Health Res., 11(4): 205-9.

Tammam, A.; Haridy, M.; Abdellah, A.H.; Ahmed, S.R.; Fayed, H.M. and Alsammani, M.A. (2013): seroepidemiology of T. gondii spontaneous miscarrige in the first trimester in Qena govornorate, Egypt. J. Clin. Diag. Res., 7(12): 2870-2873.

Tilahun, B.; Hailu, Y.; Tilahun, G.; Ashenafi, H.; Vitale, M.; Di Marco, V. and Gebremedhin, E.Z. (2016): Seroprevalence and risk factors of $T$. gondii infection in humans in East Hararghe Zone, Ethiopia. Epidemiol. Infect., 144(1): 64-71.

Tomasoni, L.R.; Sosta, E.; Beltrame, A.; Rorato, G.; Bigoni, S.; Frusca, T.; Zanardini, C.; Driul, L.; Magrini, F.; Viale, $P$. and Castelli, $F$. (2010): Antenatal screening for mother to child infections in immigrants and residents: The case of toxoplasmosis in Northern Italy. $J$. Immigrant Minority Health, 12(6): 834-40.

Torgerson, P.R. and Macpherson, C.N. (2011): The socioeconomic burden of parasitic zoonoses: global trends. Vet. Parasitol., 182(1): 79-95.

Wahab, T.; Edvinsson, B.; Palm, D. and Lindh, J. (2010): Comparison of the AF146527 and B1 repeated elements, two real-time PCR targets used for detection of T. gondii. J. Clin. Microbiol., 48(2): 591-2.

Weiss, L.M. and Dubey, J.P. (2009): Toxoplasmosis: a history of clinical observations. Int. J. Parasitol., 39(8): 895-901.

Younis, E.E.; Abou-Zeid, N.Z.; Zakaria, M. and Mahmoud, M.R. (2015): Epidemiological studies on toxoplasmosis in small ruminants and equine in Dakahlia Governorate, Egypt. Assiut Vet. Med. J., 61(145): 22-31.

\section{الآثار الصحية العامة لمرض التوكسوبلازما فى الحيوانات والسيدات فى مناطق مختارة بمحافظة المنوفية ، مصر \\ أحمد بييومى ، شريف زبيان ، أكرم سلامه ، أحمد الصبيفى، غادة حداد ، نورهان عيسى \\ E-mail:vet_noura@yahoo.com Assiut University web-site: www.aun.edu.eg}

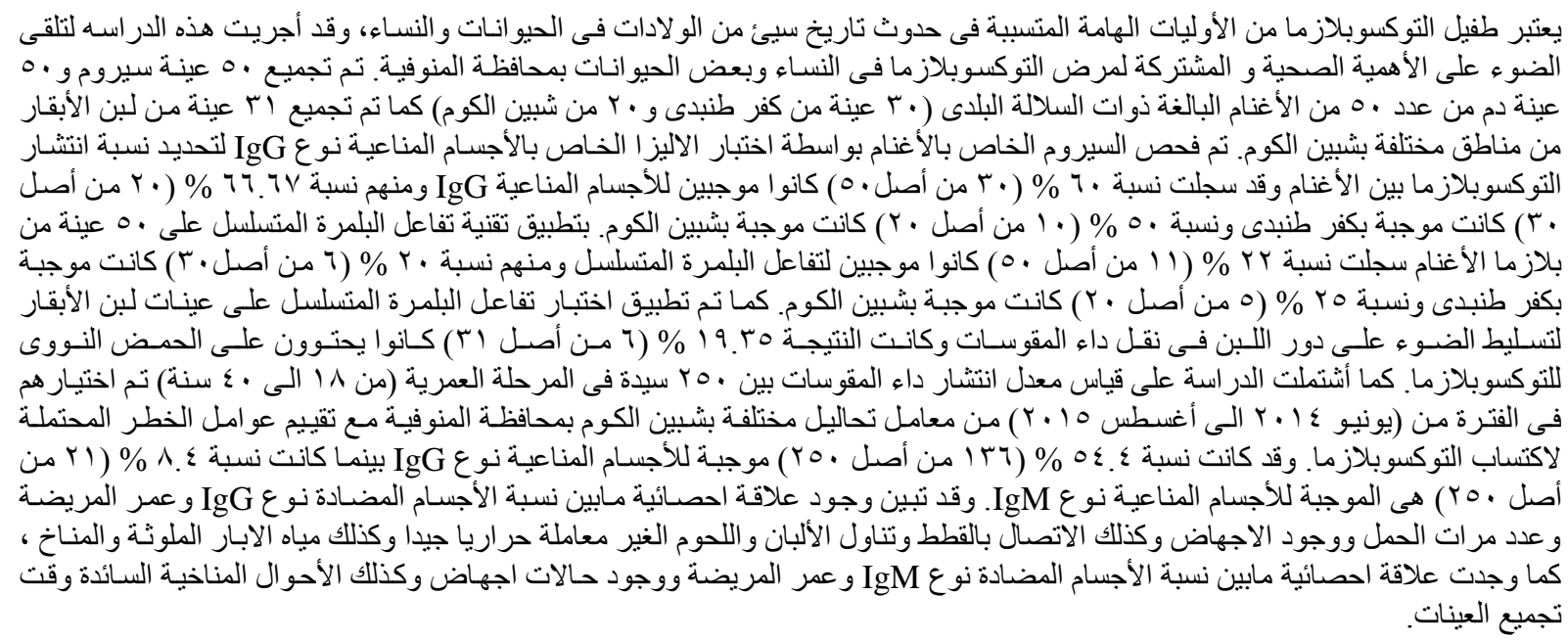

